УДК 811751

DOI: $10.17223 / 22274200 / 9 / 5$

\title{
Г.А. Толстова
}

\section{О СЛОВАРЕ СТАРООБРЯДЧЕСКОЙ ЯЗЫКОВОЙ ЛИЧНОСТИ АГАФЬИ КАРПОВНЫ ЛЫКОВОЙ}

\begin{abstract}
Статья посвящена словарю языка старообрядки-отшельнищы Агафьи Льковой, созданному на основе ее писем. Языковая личность А.К. Лыковой характеризуется как нетипичная, сформировавшаяся в уникальных условиях узкозамкнутого семейного коллектива, вне широких социальных связей. Эпистолярные источники словаря сохраняют стиль и лексику старообрядческой рукописной литературы. Рассматриваются тип словаря, его макроструктура и микроструктура, подробно освещаются особенности словарных статей, приводятся их образиыл.

Ключевые слова: языковая личность, А.К. Лькова, диалектная лексика, старообрядческая конфессиональная лексика, словарь, словарная статья.
\end{abstract}

С второй половины XX в. в науке о языке начинает активно развиваться антрополингвистика. А.А. Леонтьев отмечает: «Как бы истово мы ни верили в то, что язык - общественное явление, но вскрыть его социальную природу мы можем, только исследуя его реальное формирование и функционирование у говорящих индивидов» [1. С. 23]. В трудах Ю.Н. Караулова [2], В.П. Нерознака [3] и их последователей формируется теория языковой личности; изучаются идиолекты конкретных говорящих, в том числе диалектоносителей $[4,5]$, создаются словари представителей народно-речевой культуры [6-10].

Среди типов языковых личностей, привлекающих наиболее пристальное внимание ученых, - «рядовой» / «не рядовой» носитель языка; «типичный, рядовой, средний» носитель языка / «творческая» языковая личность [11. С. 3]; «стандартная» / «нестандартная» языковая личность [3. С. 114]. В основу деления при этом взят критерий наличия ярко выраженных индивидуальных черт в языке, в данном случае отличающихся от общепринятых норм языка социума.

При обращении к речи старообрядки Агафьи Карповны Лыковой (далее АЛ) - единственного живого представителя семьи отшельников, прожившей в саянской тайге несколько десятилетий ее языковая личность была обозначена как нетипичная [12]. Она 
сформировалась вне естественной языковой среды, развитие устной речи ограничивалось семейным общением, письменной - чтением сакральных текстов. Контакты с основными носителями русского языка (под которыми понимаются представители языковой общности, чье формирование и функционирование как языковой личности происходит в социуме) появились у Агафьи Лыковой в 34-летнем возрасте. Развитие ЯЛ старообрядки обусловлено экстралингвистическими факторами, связанными с принадлежностью к старообрядческой конфессиональной среде, проживанием семьи в отшельничестве, появлением новых условий (контактов с основными носителями русского языка) для функционирования говора, наличием индивидуальных способностей к языку.

Известные в лексикографии диалектные словари личности отражают словарный состав индивида без отрыва от естественной языковой среды [6-10]. Пример идиолекта Агафьи Лыковой интересен тем, что языковая личность проживает в микросоциуме в условиях ограниченной речевой практики.

Одной из первых о языке семьи Лыковых написала Г.Г. Белоусова [13]. Лингвистами Казанского государственного университета с 1983 по 1987 г. были предприняты 4 научные экспедиции, результатом стали фрагментарные лингвистические наблюдения устной и письменной речи АЛ $[14,15,16]$.

Истории рода Лыковых и особенностям их языка посвящены монографии «Древо Аввакума (Житие христиан Лыковых)» [17], «Полуустав в XXI веке (коллекция писем старообрядки А. Лыковой в собрании КККМ)» [18] и ряд научных статей автора данной публикации $[19,20,21]$, наиболее детально изучена старообрядческая конфессиональная лексика АЛ [22].

Обобщающим трудом, в котором отражен идиолексикон нетипичной языковой личности, стал «Словарь языка Агафьи Лыковой» [23]. Он составлен на основе письменной речи старообрядки. Источниками лексикографической обработки стали 99 писем, написанных АЛ в период с 1983 по 2003 г. Сбор материалов проводился путем комплектования в Литературном музее (филиал Красноярского краевого краеведческого музея) автором данной статьи, они хранятся в фондах этнографии и редких письменных источников.

АЛ в письмах пользуется церковнославянской графикой, сохраняет стиль и лексику старообрядческой рукописной литера- 
туры; 26 писем адресовано старообрядцам и 73 - нестарообрядцам. В первых письменных текстах (начала 1980-х гг.) явная социальная дифференциация в написании писем разным адресатам не наблюдается. Более поздние тексты писем старообрядцам и нестарообрядцам отличаются структурой, содержанием, построением фраз, использованием цитат из текстов Священного писания, графикой письма. Все письма АЛ рас-смотрены в словаре с учётом речевой и социальной характеристики адресатов писем А.К. Лыковой. Особенности графики и стиля Агафьи Карповны сохранены полностью: тексты АЛ никакой орфографической правке не подвергаются, кроме примеров дефисного написания: кто-то, коечто, во-первых.

Цель «Словаря языка Агафьи Лыковой» - отражение лексики конкретной личности, сформировавшейся в локальных условиях в отсутствие постоянных контактов с основными носителями русского языка.

Основные задачи словаря: 1) представить лексический состав идиолекта языковой личности; 2) лексикографически интерпретировать его через систему словарных помет; 3) обозначить количество употреблений отдельных слов; 4) выявить специфику словарного состава через сопоставление с данными словарей русского языка.

По типу словарь является идиолектным (поскольку отражает речевую практику одной языковой личности), полным (включает всю лексику писем АЛ); он входит в класс диалектных словарей (представляет лексику старообрядческого говора южных районов Приенисейской Сибири), относится к толково-переводным (при толковании лексики предполагает внутриязыковой перевод), лексико-ономастическим (включает в том числе и собственные имена: антропонимы и топонимы, встречающиеся в письмах и записях).

Словарный запас Агафьи Лыковой, отражённый в письменных текстах, представлен в алфавитном порядке в виде 2977 словарных статей.

В структуре словарной статьи «Словаря...» выделяются четыре зоны: зона представления, квалификационная, иллюстративная и справочно-сопоставительная зоны.

1. Зона представления начинается с заглавного слова в начальной форме: существительное в форме именительного падежа единственного числа, глагол в форме инфинитива, прилагательное в 
форме именительного падежа мужского рода единственного числа и т.д. Прилагательное приводится в женском роде в случае употребления только применительно к женскому полу: дойная (коза). Заглавное слово может быть представлено в формальных вариантах, имеющих один корень и тождественную семантику: крещение и крещенне; диявольский и дияволий; деньги и денги.

После заглавного слова даны все словоформы лексемы, имеющиеся в текстах, они указываются более мелким шрифтом в орфографии источника:

пойти; пошла, пошло, пошовъ, пошли, пойдетъ, пойду. Глаг.

Формы, различающиеся в источниках написанием, приводятся рядом: агафія, агафья; бЂъ, богъ.

Общеупотребительная лексика современного русского языка (зафиксированная без помет в «Словаре русского языка» под ред. А.П. Евгеньевой (МАС) - базовом словаре для сравнительного сопоставления исследуемых материалов [24]) - не толкуется. В зону представления входит значение слов, имеющих у АЛ отличную от данных базового словаря семантику, и сформулированное на основании контекста:

исправиться; исправилась. Глаг.; старообр. Здесь: стать годным к употреблению после освящения чтением молитв.

В речи АЛ широко представлены устойчивые сочетания и фразеологические обороты, они помещены со знаком $\diamond$ : Изнацедиться до конца (до конца изнацедиться) - нанести ущерб здоровью тяжелой физической работой.

Толкование значения таких единиц опирается на данные «Фразеологического словаря русского языка» под ред. А.И. Молоткова (М., 1986) и словаря В.И. Даля «Пословицы русского народа» (М., 1999).

2. Квалификационная зона представляет лингвистические сведения о слове при помощи словарных помет. В словаре даются грамматические и лексические пометы. 
Система грамматических помет в словаре минимальна: указывается часть речи, выделяются имена собственные - топонимы и антропонимы:

борозда; борозду. Сущу.

Абаза; доабазы, вабазе, вабазу, сабазы. Сущ., собст., топон.

Система лексических помет в словаре характеризует следующие категории словарных единиц: а) по территориальной общности (диалектная лексика); б) социальной общности (религиозная, семейная и окказиональная лексика); в) времени использования (устаревшая лексика и новые слова); г) профессиональной общности (профессиональная лексика и медицинские термины); д) эмоциональной окраске слова (уменьшительно-ласкательные, экспрессивные и образные слова).

Определение этих помет осуществлялось на основе сопоставления лексики писем АЛ с данными уже названного «Словаря русского языка».

Диалектной считается лексика, зафиксированная в 4-томном академическом словаре с пометой обл.; а также отсутствующая в нем, но отмеченная с локальной пометой в «Толковом словаре живого великорусского языка» В.И. Даля (М., 2000) либо нашедшая отражение в сводном «Словаре русских народных говоров» (М.; Л., 1965. Вып. 1 и посл.) или общих и специальных диалектных словарях Сибири и Приенисейского региона: «Словаре русских говоров южных районов Красноярского края» (Красноярск, 1988), «Словаре русской народно-диалектной речи в Сибири XVII - перв. пол. XVIII в.» (Новосибирск, 1991), "Словаре русских говоров северных районов Красноярского края» (Красноярск, 1992), «Словаре русских говоров Сибири» (Новосибирск, 1999), «Материалах к областному словарю сибирскаго наречия; Красноярский уезд Енисейской губернии» В.И. Анучина (Красноярск, 1902), «Опыте лесного словаря на материале говоров Красноярского края» К.П. Михалап (Красноярск, 1994), «Словаре рыбаков и охотников Северного Приангарья» (Красноярск, 1994), «Словаре сибирского (челдонского) говора» В.И. Чащина (Красноярск, 2003). «Словаре лексики лесного сплава XVIII - перв. пол. XX вв.» Г.Л. Гладилиной (Красноярск, 2007). Кроме того, нами использованы рукописные словари - «Краткий 
словарь кежемского говора» А.Ф. Карнаухова (Красноярский край, Кежма, 1966) и «Словарь старообрядцев титовского согласия Красноярского края» Н.Г. Сидоркиной (Красноярский край, 2002), хранящиеся в Красноярском краевом краеведческом музее.

Диалектная лексика отличается от общенародной не только более узкой сферой употребления, но и рядом других особенностей: фонетических, грамматических, лексико-семантических. В соответствии с этими особенностями выделены следующие типы диалектных слов: фонетические (диал., фонет.): давленне 'давление', взеться 'взяться', болной 'больной'; лексико-фонетические (диал. лексикофонет.): пореду 'по ряду, по порядку', владенне 'владение, сила'; лексические (диал., лексич.): лапатина 'одежда', насочить 'ошкурить'; словообразовательные (диал., словообр.): накладавать 'накладывать', натаскавать 'натаскивать'; грамматические (диал., грам.): десятой 'десятый', короткой 'короткий'. Например:

желание и желанне; желание, желаніе и желання. Сущ.; 2-е диал., фонет. Желание.

лапатина; влапатине, влапатину. Сущ..; диал., лексич. Одежда ${ }^{1}$. оказавать; оказававл. Глаг.; диал., словообр. Оказывать. пчелинной; пчелинной. Прил.; диал., грам. Пчелиный.

В словаре широко представлена сакрально-богослужебная лексика, под которой понимаем лексику религиозной сферы в целом, т.е. лексические единицы, представляющие основные понятия вероисповедной сферы, именующие идеи, образы и явления главного источника христианского вероучения - Библии, отражающие обрядовую, ритуальную сторону православной религии; и сакрализованные слова - совокупность лексических единиц, во вторичном своем значении соотносимых с понятием «вера», отражающих миропонимание ЯЛ через восприятие текстов Священного писания и ориентированных на них. Сакрально-богослужебная лексика состоит из единиц, обозначенных нами, в свою очередь, как православные и старообрядческие конфессиональные. Термином «православная лексика»

${ }^{1}$ По мнению участников разных экспедиций на Еринат Л.С. Черепанова, Э.В. Мотаковой, И.П. Назарова и др., для Лыковых это общее название одежды, об этом же говорят материалы экспедиций автора словаря. 
названа нами совокупность слов, отражающих вероисповедную сферу религии, которая включает общий для всех православных словарный фонд. Старообрядческой конфессиональной лексикой мы назвали пласт богослужебной лексики православной религии, присущий старообрядческой языковой среде.

Сакрально-богослужебная лексика и фразеология представлены пометой сакр.-богосл., при этом старообрядческие конфессиональные словарные единицы выделены пометой старообр. Автор писем - глубоко верующий человек, воспитанный на библейских заповедях, сформировавшийся в особых условиях восприятия священных текстов, ведёт иноческий образ жизни, в религиозной лексике отражено мировосприятие старообрядцев. При толковании религиозных лексических единиц использовались данные богословских словарей: «Большого путеводителя по Библии» (М., 1993), «Полного православного богословского энциклопедического словаря» (М., 1992); «Полного церковно-славянского словаря». (М., 1998); энциклопедического словаря С.Г. Вургафта и И.А. Ушакова «Старообрядчество. Лица, предметы, события и символы» (М., 1996):

правило; правило, правила. Сущ.; диал., семант.; сакр.богосл. 1. Постановления Вселенских и Поместных соборов. 2. Установленное богослужение; молитвы, читаемые в определенных случаях.

братия; братии, братіи. Сущ.., собир.; сакр.-богосл, старообр. Здесь: старообрядческая община. $\diamond \mathrm{O}$ христе братия - сообщество строгих (крепких) старообрядцев.

Квалификационная зона содержит также временную характеристику слова: устаревшая лексика отражена в пометах ycmap. (наипаче 'более всего', лани 'в прошлом году'), истор. (керженка 'река в Нижегородской области, Керженец - один из духовных центров старообрядчества'); новые понятия, вошедшие в жизнь АЛ с 1980-х гг., нашли отражение в словаре с пометой нов.: поезд, верталет 'вертолет', аперацыя 'операция': 
аперацыя; саперацый. Сущ.; диал. фонет.; мед., ${ }^{1}$ нов. Операция.

$\mathrm{C}$ целью уточнения семантики религиозной и устаревшей лексики из лексикона старообрядки она сопоставляется также с данными исторических словарей: «Словаря древнерусского языка XI-XIV вв.» (M., 1988-2008); «Словаря русского языка XI-XVII вв.» (М., 1975-2001); «Словаря русского языка XVIII в.» (Л., 1984-1995); «Словаря архаизмов» (М., 2001); «Словаря языка мангазейских памятников XVII - перв. пол. XVIII в.» Н.А. Цомакион (Красноярск, 1971).

В словаре отражена, кроме того, семейная лексика (под которой понимаются лексические единицы, бытующие только в узкосемейном кругу Лыковых; они выделялись при сопоставлении с данными региональных диалектных словарей, а также в результате общения с А.К. Лыковой: семей.: заоблегчивать 'полегчать', испростудить 'застудить, подвергнуть переохлаждению'); окказиональная лексика (окказ.: ветрадуйка 'холодная изба'); профессиональная (проф.: вагонка 'строительный материал, доски определенного размера'); медицинские термины (мед.: меновазин 'лекарственный препарат, мазь'); лексика экспрессивная (экспресс.: всеядовитый 'вредный, смертоносный') и образная (образн.: молотить 'болтать').

Имена собственные в словаре (помет. собст.) дают представление о сфере общения Агафьи Карповны Лыковой, ориентируют читателя в пространстве:

Абакан; наабаканъ, доабакана, сабакана, вабакан, абаканъ, вабаканъ. Сущ., собст., топон. 1. Река, правый приток Енисея. 2. Город, столица Хакасии.

Топонимы, включенные в словарь, проверены по «Топонимическому словарю Хакасско-Минусинского края» В.Я. Бутанаева (Абакан, 1995), изданию «Почему так названы: Топонимический словарь, топонимические очерки» Ю.Р. Кисловского, «Словарю топонимов и микротопонимов Красноярского края» (Красноярск, 2000).

\footnotetext{
${ }^{1}$ Помета при медицинских терминах.
} 
При лексикографировании антропонимов проведена тщательная работа по их атрибутированию:

Дунаева; дунаевой, д. Сущ., собст. Женская фамилия. Здесь: Галина Ивановна Дунаева - пенсионерка из г. Пушкино Московской области, жила на Еринате летом 1990 г.

3. Иллюстративная зона представляет примеры употребления слов в контексте с указанием источника. Источник указывается в круглых скобках после примера: первая цифра - номер письма, вторая - номер страницы.

В конце иллюстративной зоны приводится количество употреблений слова. По употребительности слова подразделяются на группы: единичные - до 5 употреблений, редкие - до 10 , распространённые - до 30, частотные - более 30. Данные «Словаря языка Агафьи Лыковой» по частотности лексем выявляют следующую картину: единичные: 2087 - 70,1\%; редкие: 209 - 7,02\%; распространенные: $204-6,85 \%$; частотные: $166-5,57 \%$.

Каждая лексема иллюстрируется 10 примерами. От 10 до 30 употреблений указываются в словарной статье по источникам, частотные же лексемы обозначаются пометой «и т.п.». В примерах представляются значения и оттенки значения в различных контекстах:

дело; дело, деломъ, оделе, поделамъ, надело, задело, дела, вделахъ. Сущц.

$\diamond$ Главное дело. $\diamond$ Грешное дело. Религ. СМол: ${ }^{1}$ нет. $\diamond$ Греховно дело - поступок, приводящий к совершению греха. Религ. СМол: нет. $\diamond$ Духовное дело - вероучение, богослужебные обряды. Религ. СМол: нет. $\diamond$ Пустынное дело - образ жизни, поведение в уединенном безлюдном месте. $\diamond$ Такое дело. СМол: нет. $\diamond$ Опасное дело. СМол: Гиблое дело - ни к чему к хорошему не приведёт; опасно, гибельно (делать что-либо).

самое главное дело чтобы вдому миръ бывъ илюбовь $(10,4-5)$. левъ ст ч/Степанович Черепанов/ заето дело взавса избавить етой

\footnotetext{
${ }^{1}$ Сокращение обозначает данные проверки по «Фразеологическому словарю русского языка» под ред. А.И. Молоткова.
} 
беды $(12,1)$. анисимъ мне зять заанисимомъ ия сестры двоюродны ивотъ такое дело $(16,1-2)$. анисимъ тропинъ тоже поспрашевала унихъ одуховномъ деле $(17,1-2)$. я бы очень стобой хотела повидатса ипоговорить одуховномъ деле $(18,2)$. подомашнымъ деламъ работаю, ибЂу /Богу/ молюсь $(19,1-2)$. время нету писать обетомъ деле $(21,1-2)$. остановите козу дойну разыскивать, пока, ето дело оставить $(35,2)$. воть такое дело скозами $(35,8)$. нокогда я ето, ивану седмова августа сказава ему нипустыннымъ деломъ занявса надо летомъто дровъ заготовит дакозамъ корму дакъ онъ страшно наменя разъяривса $(120,5)$.

$(9,1 ; 21,1-2 ; 21,1-2 ; 28,1 ; 39,3-4 ; 39,3-4 ; 40,1-2 ; 44,4-6 ; 46$, 2 ; 48, 3-4; 48,4-5; 48, 4-5; 53, 1-3; 54, 3-4; 54, 3-4; 54, 3-4; 59, 1-2; 60,$1 ; 60,4$ и т.д.).

MAC: есть.

В косых скобках дана расшифровка:

- сокращенных слов, принятых в церковнославянском языке: гDи /Господи/, истмыхъ оц7ъ /и святых отцов/;

- букв, использованных автором писем при передаче фамилий и инициалов людей: левъ с ч /Степанович Черепанов/, игорь п /Павлович/, а н /Александра Наумовна/;

- славянских цифр при обозначении чисел и дат: выбывъ ссевера i /10/ декабря писала агафія;

- даны пояснения, уточнения к сокращённым предложениям (особенность автора писем - построение сложных, громоздких предложений): нонче они погулялись суягны, иболеють тоже /о козах/.

4. В сравнительно-сопоставительную зону включены для сопоставления данные МАC, диалектных, исторических, богословских, топонимических словарей, перечисленных выше. Приведем примеры сравнительно-сопоставительной зоны словарной статьи для областного слова лапатина:

$\mathrm{B}^{1}$ : лопоть, лопотина - верхняя одежда рабочая и особ. праздничная. Г: лопатина, лопастина с другим значением. Кар: лопать, лопатина - одежда. ДТ: тоже лопать, лопотной, лопотина верхняя одежда; Арх., Вят., Сиб. Пан: лопотина, лопоть - одежда. СРГС: лопотина, лопоть - 1) общее название одежды; 2) верхняя

${ }^{1}$ Буквами и аббревиатурами в словарных статьях обозначены названия словарей, привлекавшихся для сопоставления материала. 
одежда; 3) старая поношенная одежда. СРНГ: лопотина - одежда; Волог., Костром., Арх., Вят., Нижегор., Киров., Перм., Север., Свердл., Челяб., Курган., Тобол., Новосиб., Краснояр., Енис., Иркут., Забайк. СЦГ: лопотина, лопоть - одежда; лопотинка, лопотишко одежда (уничиж.). СЮГ: лопотина - 1) общее название одежды; 2) предмет одежды. ССГ: лопотина - одежда. CXI-XVII: лопоть одежда, главным образом рабочая; лопотье - одежда, старая одежда. CXVIII: лопоть и лопотье - ветхая одежда. Ц: лопоть, лопотинка, лопотишка - одежда. Ч: лопоть - одежда. МАС, А, Мих, Пет, СА, Сид: нет;

лексемы из религиозной сферы правило:

MAC: есть, с др. знач. - 1) положение, выражающее определенную закономерность, постоянное соотношение каких-либо явлений; 2) положение, установка, принцип, служащие руководством в чем-л. CXI-XIV: правило - 1) установленное правило, канон; 2) норма поведения жизни. Ц: правленье - 1) установленное богослужение. CXI-XVII: правило - 9) церковный канон, правило. CXVIII: 9) церковный канон, правило; 10) устав, свод правил. ПБС: правильник богослужебная книга, относящаяся к частному богослужению и содержащая для священнослужителей, готовящихся совершать литургию, и для мирян, намеревающихся приступить к таинству евхаристии, «правило» как приготовлять себя к принятию св. тайн Христовых, а также самые службы и молитвословия, требуемые правилом. Правило печатается также в «Служебнике» и в Следованной Псалтири. В конце книги находится «Известие учительное», помещаемое также в конце «Служебника». ПЦС: правила или каноны церкви утвердившись обычаем, были преданы письмени в 3 в. К 85 правилам апостольским присоединены правила вселенских и поместных соборов и знаменитейших отцов. Объяснения правил писали Зонара, Алексей Аристин, Федор Вальсамон и пр. Сборник правил с прибавлением законов византийских императоров был назван Номоканоном и Кормчей книгой. В подлинном виде правила изданы в «Книге правил». Ск: последовательность молитв, читаемых в определенное время и с определенной целью. Ц: правление - установленное богослужение. БПБ, Пан, СА, Ст: нет;

топонима Абакан:

B: Название города от «Абакана», правого притока р. Енисей. Элемент аба восходит к древнему этнониму аба, абалар; кан нере- 
док в гидронимах Сибири в значении река. Распространенное объяснение гидронима А. «медвежья кровь» ошибочно. Кис: Название города от реки Абакан. Этимология названия реки имеет несколько вариантов, в том числе народное истолкование из древних хакасских легенд. По мнению автора, первая часть происходит либо от имени древнего племени абинцев, либо от хакасского со значением «медвежий». Вторая часть его, распространённый в Южной Сибири гидроним кан, происходит либо от слова со значением «река, приток большой реки» (канг), либо от слова «река» (кан) на языке древних тюркских племён. Б: нет.

Как показывают данные «Словаря языка Агафьи Лыковой», лексическая система идиолекта состоит из следующих компонентов: 1) общерусская лексика; 2) диалектная лексика старожильческого населения южных районов Красноярского края, сложившаяся в результате смешения говоров севернорусского и южнорусского происхождения; 3) сакрально-богослужебная лексика; 4) семейная и окказиональная лексика.

В письменной речи старообрядки доминирует книжная лексика. Её эпистолярные тексты ориентированы на традиции древнерусских житий. В лингвистических исследованиях русских народных говоров процент диалектных слов по отношению к общерусской лексике сильно колеблется: 4-5\% у Г.И. Мельниченко [25. С. 4], от 12 до $20 \%$ у В.А. Сенкевича [26. С. 55], 14\% (и 43,8\% диалектных вариантов общерусских слов) у О.И. Блиновой [27. С. 43], около $1 / 4$ части у Н.Т. Бухаревой [28. С. 97], 32,5\% у Н.А. Лукьяновой [29. 5], 10\% у В.П. Тимофеева [6. С. 17, 19], 39,86\% у Е.В. Иванцовой (включая диалектные варианты общерусских слов, собственно диалектные слова, диалектно-просторечные слова, диалектно-просторечные варианты общерусских слов, диалектные варианты диалектнопросторечных слов) [9. С. 40-43]. Сравнение нами данных О.И. Блиновой $(43,8 \%)$ и подсчетов по «Полному словарю диалектной языковой личности» Е.В. Иванцовой (около 40\%) с данными «Словаря языка Агафьи Лыковой» (524 лексемы - 17,6 \% от 2977 словарных единиц) свидетельствует о значительно меньшем числе диалектных элементов в языке старообрядки. Причина этого факта, очевидно, в отсутствии живой диалектной языковой среды и в ориентации языковой личности на книжную лексику, что обусловлено чтением старопечатных книг и текстов старообрядческой литерату- 
ры. В соотношении предметная / отвлеченная (абстрактная) лексика превалируют предметные лексические единицы, что связано с мировосприятием языковой личности, выросшей в строгой, консервативной старообрядческой среде. Данное явление у рядовых диалектоносителей лингвисты объясняют особенностью народного мировосприятия (см., например, [5]).

В «Словаре языка Агафьи Лыковой» лексикографически обработаны и введены в научный оборот уникальные материалы писем старообрядки-отшельницы - языковой личности, сформировавшейся в микросоциуме и сохранившей особенности развития русского языка разных эпох (полууставное письмо, диакритические знаки, лексико-семантические значения слов).

В настоящее время подготовлено второе дополненное и исправленное издание словаря, которое планируется издать под названием «Словарь языка старообрядки А.К. Лыковой». В нем отражены новые материалы эпистолярия информанта (круг источников пополнился 32 письмами АЛ), значительно расширен словник (на данный момент он составляет около 4000 словарных статей). В процессе переработки внесены исправления в толкование ряда лексических значений слов; уточнена и расширена система помет. Публикация «Словаря языка старообрядки А.К. Лыковой» даст новые ценные материалы для изучения диалектной языковой личности из старообрядческой конфессиональной среды.

\section{Литература}

1. Леонтьев А.А. Объект и предмет социолингвистики и ее отношение к другим наукам о речевой деятельности // Теория речевой деятельности. - М.: Наука, 1968. C. $14-31$.

2. Караулов Ю.Н. Русский язык и языковая личность. - М.: Эдиториал УРСС, 2002. $-264 \mathrm{c}$.

3. Нерознак В.П. Лингвистическая персонология: к определению статуса дисциплины // Язык. Поэтика. Перевод. - М., 1996. - С. 112-116.

4. Лютикова В.Д. Языковая личность: идиолект и диалект: дис. ... д-ра филол. наук. - Екатеринбург, 2000. - 316 с.

5. Иванц̧ова E.B. Феномен диалектной языковой личности. - Томск: Изд-во Том. ун-та, 2002. -312 с.

6. Тимофеев В.П. Диалектный словарь личности. - Шадринск, 1971. - 141 с.

7. Лютикова В.Д. Словарь диалектной личности. - Тюмень: Изд-во Тюм. гос. ун-та, 2000. - $188 \mathrm{c}$. 
8. Нефёдова Е.А. Экспрессивный словарь личности. - М.: Изд-во Моск. ун-та, 2001. $-144 \mathrm{c}$.

9. Иванцова E.B. Идиолектный словарь сравнений сибирского старожила. Томск: Изд-во Том. ун-та, 2005. - 162 с.

10. Полный словарь диалектной языковой личности / под ред. Е.В. Иванцовой. Томск: Изд-во Том. ун-та, 2006-2012. - Т. 1-4.

11. Чулкина Н.Л. Модель лексикона носителя русского языка как способ представления лексической системы: автореф. дис. ... канд филол. наук. - М., 1987. $14 \mathrm{c}$.

12. Толстова Г.А. Условия формирования и функционирования нетипичной языковой личности старообрядки-отшельницы А. Лыковой // Материалы регион. науч.-практ. конф. «Язык и социальная динамика» 24 мая 2008 г., Красноярск, Сибирский государственный аэрокосмический университет им. М.Ф. Решетнева. Красноярск, 2008. - С. 35-38.

13. Белоусова Г.Г. Определение диалектной основы одного сибирского старообря дческого говора по данным лингвистической географии (на примере говора семьи Лыковых) // Тез. докл. конф. Ин-та рус. Яз. АН СССР. Ужгород, 1984. C. 64-68.

14. Альмухамедова 3.М., Маркелов В.С., Слесарева Г.П. и др. Из наблюдений над речью Лыковых - старожилов на реке Абакан // Фонетика и письмо. - Устинов, 1986. - C. 103-115.

15. Маркелов В.С. Письма Агафьи Лыковой // Русская речь. - 2000. - № 3. C. $65-73$.

16. Слесарева Г.П. Звуковой портрет Агафьи Лыковой // Материалы Междунар. съезда русистов в Красноярске. - Красноярск, 1997. - Т. 1. - С. 173-174.

17. Толстова Г.А. Древо Аввакума (Житие христиан Лыковых). - Красноярск, 2008. $-80 \mathrm{c}$.

18. Толстова Г.А. Полуустав в XXI веке (письма Агафьи Лыковой в собрании Красноярского краевого краеведческого музея). - Красноярск: ЛИТЕРА-принт, 2011. - $140 \mathrm{c}$.

19. Толстова Г.А. Культура языковой личности: Религиозная лексика в письмах старообрядки Агафьи Лыковой // Русский язык и культура речи: Сб. материалов семинара-конференции, Красноярск, 14-16 марта 2006. - Красноярск, 2006. - С. 246256.

20. Толстова Г.А. Отражение сакрального мировосприятия в языке старообрядки Агафьи Лыковой // Старообрядчество: история и современность, местные традиции, русские и зарубежные связи: материалы V Междунар. конф., 31 мая - 1 июня 2007 г., Улан-Удэ. - Улан-Удэ, 2007. - С. 262-272.

21. Толстова Г.А. Сакрализация понятий «книга» и «грамотность» «крепкими» староверами в Приенисейской Сибири (по материалам экспедиционных исследований) // Образование и глобализация: материалы III Байкальской междунар. конф. Улан-Удэ, Бурятский государственный университет, 1-4 июля 2009 г. - Улан-Удэ, 2009. - Ч. 2. - С. 243-246.

22. Толстова Г.А. Старообрядческая конфессиональная лексика в письменной речи Агафьи Лыковой: дис. ... канд. филол. наук. - 461 с. Приложение к диссертации: Языковая личность А.К. Лыковой. - 133 с. - Кемерово, 2007. 
23. Толстова Г.А. Словарь языка Агафьи Лыковой. - Красноярск: Изд-во КГПУ им. В.П. Астафьева, 2004. - 562 с.

24. Словарь русского языка: в 4 т. - М.: Рус. яз., 1981-1984.

25. Мельниченко Г.И. Характеристика словарного состава местного говора по степени употребительности слов // Докл. на научн. конф. 1962. - Ярославль, 1962. Т. 1, вып. 2. - С. 245-254.

26. Сенкевич В.A. Исследование лексических и аффиксальных особенностей функционирования русского языка. - Челябинск, 1973. - 267 с.

27. Блинова О.И. Введение в современную региональную лексикологию. Томск: Изд-во Том. ун-та, 1975. - 257 с.

28. Бухарева Н.Т. О специфике лексического состава русских говоров Сибири // Вопр. языка и литературы. - Новосибирск, 1968. - Вып. 2, ч. 1. - С. 88-100.

29. Лукьянова Н.А. Системные отношения в лексике говоров Сузунского и Ордынского районов Новосибирской области: автореф. дис. ... канд. филол. наук. Новосибирск, 1966. - 19 с.

\section{ON THE DICTIONARY OF THE OLD BELIEVER LANGUAGE PERSONALITY OF AGAFYA KARPOVNA LYKOVA}

Voprosy leksikografii - Russian Journal of Lexicography. 2016. 1 (9). 64-81.

DOI: $10.17223 / 22274200 / 9 / 5$

Tolstova Galina A., Krasnoyarsk Literary Museum (Krasnoyarsk, Russian Federation).

E-mail: tgakras@bk.ru

Keywords: language personality, A.K. Lykova, dialect vocabulary, old believer confessional vocabulary, dictionary, lexical article.

The thought about the priority of individual language acquires increasingly more supporters. Typical and untypical language personalities are studied by linguists. The author studies the brightest example of an untypical language personality, the Old Believer Agafya Karpovn Lykova, the only living representative of the family of recluses that lived in the Sayan taiga for several decades. The formation and functioning of the language personality of the Old Believer is caused by extralinguistic factors connected with the belonging to the Old Believer confession, the family living in reclusion, the new conditions for the dialect functioning due to frequent contacts with representatives of society, the individual language ability.

A noticeable contribution to the study of the language of the Old Believer is The Dictionary of Agafya Lykova's Language. The sources of the lexicographical processing were 99 letters that the language personality wrote in the period from 1983 to 2003.

The purpose of The Dictionary of Agafya Lykova's Language is the reflection of the vocabulary of the concrete personality which was formed under the local conditions in the absence of fixed contacts with major Russian language speakers.

The basic tasks of the dictionary are 1) to present the lexical composition of the idiolect of the language personality; 2) to interpret it lexicographically through the system of lexical marks; 3) to designate the number of uses of individual words; 4) to reveal the specific character of the vocabulary through the comparison with the data of the dictionaries of the Russian language.

According to its type the dictionary is complete (since it includes the entire vocabulary of Lykova's letters); it belongs to dialect dictionaries of a language personality (it 
presents the vocabulary of the Old Believer dialect of the southern regions of Yenisei Siberia), to explanatory-translation (it assumes intralingual translation) and lexical-onomastic (it includes proper names: anthroponyms and toponyms from the letters and records).

The vocabulary of Agafya Lykova, reflected in the written texts, is represented in the alphabetical order in the form of 2977 entries.

The structure of the entry includes four zones: a zone of representation, a zone of qualification, an illustrative zone and a comparative zone.

1) The zone of representation begins from the title word in the initial form, then word forms are given that exist in the texts.

2) The zone of qualification presents linguistic information about the word by the use of lexical marks.

3) The illustrative zone presents examples of the use of words in the context with the indication of the source. At the end of the illustrative zone the number of word uses is given.

4) The comparative zone uses data of 27 dictionaries (explanatory, general dialect, local dialect, toponymic, theological, historical, of obsolete words, of phrases and idioms). The basic dictionary in this case is The Dictionary of the Russian language (Moscow, 1981-1984). Each word of the Lykova's language dictionary is verified in this edition to attribute it to classes of lexical units.

As the data of The Dictionary of Agafya Lykova's Language show, the lexical system of the idiolect consists of the following components: 1) all-Russian vocabulary; 2) dialect vocabulary of the old-resident population of the southern regions of Krasnoyarsk Krai which originated as a result of the mixing of the North-Russian and South-Russian dialects; 3) sacral liturgical vocabulary; 4) family and occasional vocabulary.

The practical significance of The Dictionary of Agafya Lykova's Language consists in the fact that unique materials are assembled, systematized, lexicographically processed, represented in the dictionary and introduced into the scientific use: letters of the Old Believer recluse, the language personality which was formed in a micro-society and preserved special features of the development of the Russian language of different epochs.

\section{References}

1. Leont'ev, A.A. (1968) Ob"ekt i predmet sotsiolingvistiki i ee otnoshenie k drugim naukam o rechevoy deyatel'nosti [Object and The subject and object of sociolinguistics and its relation to other sciences about the speech activity]. In: Leont'ev, A.A. Teoriya rechevoy deyatel'nosti [The theory of speech activity]. Moscow: Nauka.

2. Karaulov, Yu.N. (2002) Russkiy yazyk i yazykovaya lichnost' [The Russian language and language personality]. Moscow: Editorial URSS.

3. Neroznak, V.P. (1996) Lingvisticheskaya personologiya: k opredeleniyu statusa distsipliny [Linguistic personology: on the determination of the status of discipline]. In: Yazyk. Poetika. Perevod [Language. Poetics. Translation]. Moscow: Moscow State Linguistic University.

4. Lyutikova, V.D. (2000) Yazykovaya lichnost': idiolekt i dialekt [Language personality: idiolect and dialect]. Philology Dr. Diss. Ekaterinburg.

5. Ivantsova, E.V. (2002) Fenomen dialektnoy yazykovoy lichnosti [The phenomenon of the dialect language personality]. Tomsk: Tomsk State University. 
6. Timofeev, V.P. (1971) Dialektnyy slovar' lichnosti [The dialect dictionary of personality]. Shadrinsk.

7. Lyutikova, V.D. (2000) Slovar' dialektnoy lichnosti [The dictionary of dialect personality]. Tyumen: Tyumen State University.

8. Nefedova, E.A. (2001) Ekspressivnyy slovar' lichnosti [The expressive dictionary of personality]. Moscow: Moscow State University.

9. Ivantsova, E.V. (2005) Idiolektnyy slovar' sravneniy sibirskogo starozhila [The idiolect dictionary of the comparisons of a Siberian old resident]. Tomsk: Tomsk State University.

10. Ivantsova, E.V. (ed.) (2006-2012) Polnyy slovar' dialektnoy yazykovoy lichnosti [Complete Dictionary of the Dialect Language Personality]. Vols 1-4. Tomsk: Tomsk State University.

11. Chulkina, N.L. (1987) Model' leksikona nositelya russkogo yazyka kak sposob predstavleniya leksicheskoy sistemy [Model of the lexicon of the Russian language speaker as a method of lexical system representation]. Abstract of Philology Cand. Diss. Moscow.

12. Tolstova, G.A. (2008) [Conditions of formation and functioning of the untypical language personality of the Old-Beliver and recluse A. Lykova]. Yazyk $i$ sotsial'naya dinamika [Language and social dynamics]. Proceedings of the regional practical-scientific conference. 24 May 2008. Krasnoyarsk: Siberian State Aerospace University. pp. 35-38. (In Russian).

13. Belousova, G.G. (1984) [Determination of the dialect basis of a Siberian Old Believer dialect according to the data of linguistic geography (based on the example of the dialect of the Lykov family)]. Theses of the reports at the conference of the Institute of the Russian Language, USSR AS. Uzhgorod. pp. 64-68. (In Russian).

14. Al'mukhamedova, Z.M. et al. (1986) Iz nablyudeniy nad rech'yu Lykovykh starozhilov na reke Abakan [From the observations of the speech of the Lykovs, old residents on the Abakan river]. In: Fonetika i pis'mo [Phonetics and writing]. Ustinov.

15. Markelov, V.S. (2000) Pis'ma Agaf'i Lykovoy [Agafya Lykova's Letters]. Russkaya rech'. 3. pp. 65-73.

16. Slesareva, G.P. (1997) Zvukovoy portret Agaf'i Lykovoy [The sound portrait of Agafya Lykova]. Proceedings of the international congress of philologists in Krasnoyarsk. Vol. 1. Krasnoyarsk. pp. 173-174. (In Russian).

17. Tolstova, G.A. (2008) Drevo Avvakuma (Zhitie khristian Lykovykh) [Tree of Habakkuk (The Life of the Lykovs, Christians)]. Krasnoyarsk: Trend.

18. Tolstova, G.A. (2011) Poluustav v XXI veke (pis'ma Agaf'i Lykovoy v sobranii Krasnoyarskogo kraevogo kraevedcheskogo muzeya) [Semi-uncial in the 21st century (Agafya Lykova's letters in the collection of Krasnoyarsk Regional Museum of Local Lore)]. Krasnoyarsk: LITERA-print.

19. Tolstova, G.A. (2006) [Culture of the language personality: Religious vocabulary in the letters of the Old Believer Agafya Lykova]. Russkiy yazyk $i$ kul'tura rechi [The Russian language and the culture of speech]. Proceedings of the seminar-conference. 14-16 March 2006. Krasnoyarsk. pp. 246-256. (In Russian).

20. Tolstova, G.A. (2007) [Reflection of the sacral world view in the old believer Agafya Lykova's language]. Staroobryadchestvo: istoriya i sovremennost', mestnye traditsii, russkie $i$ zarubezhnye svyazi [Old Belief: history and the present, local traditions, the Russian and foreign connections]. Proceedings of the V international conference. 31 May 1 June 2007. Ulan-Ude. pp. 262-272. (In Russian). 
21. Tolstova, G.A. (2009) [Sacralization of concepts "book" and "literacy" by "strong" Old Believers in Yenisei Siberia (based on materials of expedition studies)]. Obrazovanie i globalizatsiya [Education and globalization]. Proceedings of II Baikal international conference. 1-4 July 2009. Pt. 2. Ulan-Ude: Buryat State University. pp. 243-246. (In Russian).

22. Tolstova, G.A. (2007) Staroobryadcheskaya konfessional'naya leksika v pis'mennoy rechi Agaf'i Lykovoy [Old Believer confessional vocabulary in the written language of Agafya Lykova]. Philology Cand. Diss. Kemerovo.

23. Tolstova, G.A. (2004) Slovar' yazyka Agaf'i Lykovoy [Dictionary of Agafya Lykova's language]. Krasnoyarsk: Krasnoyarsk State Pedagogical University.

24. Ozhegov, S.I. (1981-1984) Slovar' russkogo yazyka [Dictionary of the Russian language]. Vols 1-4. 2nd ed. Moscow: Russkiy yazyk.

25. Mel'nichenko, G.I. (1962) [Description of the vocabulary of a local dialect according to the degree of word usage]. Proceedings of the conference. Vol. 1. Pt. 2. Yaroslavl. pp. 245-254. (In Russian).

26. Senkevich, V.A. (1973) Issledovanie leksicheskikh i affiksal'nykh osobennostey funktsionirovaniya russkogo yazyka [Study of the lexical and affixal special features of the functioning of the Russian language]. Chelyabinsk.

27. Blinova, O.I. (1975) Vvedenie v sovremennuyu regional'nuyu leksikologiyu [Introduction to contemporary regional lexicology]. Tomsk: Tomsk State University.

28. Bukhareva, N.T. (1968) O spetsifike leksicheskogo sostava russkikh govorov Sibiri [On the specific character of the lexical composition of the Russian dialects of Siberia]. In: Voprosy yazyka i literatury [Questions of language and literature]. Is. 2:1. Novosibirsk. pp. 88-100.

29. Luk'yanova, N.A. (1966) Sistemnye otnosheniya v leksike govorov Suzunskogo $i$ Ordynskogo rayonov Novosibirskoy oblasti [System relations in the vocabulary of the dialects of the Suzunsky and Ordynsky districts of Novosibirsk Oblast]. Abstract of Philology Cand. Diss. Novosibirsk. 